\title{
Carpet in the Aq Qoyunlu Turkmen Period
}

Karim MİRZAEE*

\section{ÖZET}

15.Yüzyıl ortalarında Teymuriler doğuda, Osmalılar batıda Ak Koyunlular ise ikisinin arasındaki bölgede hüküm sürmüşlerdir. Osmanlılar ve Ak Koyunlular arasındaki ilişkiler sayesinde Batı ile kurulan ilişkiler sonucunda Türkmenlerin sanatına dair çok değerli bilgiler, batılı büyükelçiler ve araştırmacılar vasıtasıyla, günümüze kadar gelmiştir. Örneğin Josafa Barbaro, Tebriz Heşt Behişt Sarayı'nın güzelliklerini anlatırken, anlatımında büyük bir ipek halıya işaret etmiştir. Kendisi, sanatsal ayrıntı vermemekle birlikte, elimizdeki örnekler incelendiği zaman, bu halıların genel özelliklerini ortaya koyan tipolojisi tarifleyebiliriz. Türkmen halılarının çoğu, haşye (bordür) leri Küfi süsleme deseni ile vurgulanmıştır; Ayrıca Selcuklu haşyesi olarak bilinen bu desenler, Selcuklu, İlhanlı ve Celayiriler zamanından kalmıştır. Küfi desenler sadece haşyede değil, zemin ve göbeklerde de kullanılmıştır.

Türkmen halılarının genel tasarımı incelendiğinde; "halı yüzeyi" el yazmalarıyla doldurulmuştur. Haveran name ve hamse i nizami bu sözü edilen el yazmalarıla süslenen halılar arasında sayılabilir. Halı yüzeyini kaplayan bu yazı çeşitleri, Filologlar için de ayrı bir paleografik araştırma konusudur.

Safevi ve Osmanlı halıları belirgin bir şekilde Ak Koyunlu geleneğinden çıkarılarak kendi tipolojileri doğrultusunda sınıflandırılabilir.
Zira çeşitli uygarlıklar Tebriz'i kendilerine başkent olarak seçmişlerdir. Zira Şah İsmail, İlhanlı, Al-1 Celayir, Kara Koyunlu ve Ak Koyunlu başkenti olan Tebriz'i aynı zamanda kendilerine başkent olarak seçmişlerdir. Bilindiği üzere, Sultan Selim Han, Çaldıran muharebesi sonrasında, çok sayıda Tebrizli sanatçıyı İstanbul'a davet etmiştir.

Anahtar kelimeler: Halı, Türkmen, Ak Koyunlu, Tebriz, Desen

\section{ABSTRACT}

Contemporaneous with Timurids in East and Ottoman in West, Aq Qoyunlus ruled in the mid $-15^{\text {th }}$ century, in a territory between them. Thanks to Aq Qoyunlus relationship with west, there are valuable information left from western ambassadors and scholars about Türkmen art. For example Josafa Barbaro, describing the beauties of Tabriz Hasht Behesht palace, refers to a big silk carpet spread on the palace's floor. Of course, he does not give the artistic detail, but we can estimate its general characteristics based on typical imagery and patterns of the era. Margins of Türkmen carpets are punctuated with Kufi embellishment patterns; this patterns, also known as Saljoughi margin, are left from the time of the Saljugids, Ilkhanids, and Al i Jalayer. Kufi patterns are used not only in the margin but also in the ground and medallion.

Türkmen carpets have been frequently dealt with in several manuscripts including Khavaran Nameh, and Nezami's Khamseh. 
Safavid and Ottoman carpets can rightly be categorized as the direct descendant of Aq Qoyunlu tradition, since Shah Ismail selected Tabriz - the same capital city of Ilkhanid, Al I Jalayer, Qara Qoyunlus and Aq Qoyunlus - as his capital and Sultan Selim transferred most of the artist from Tabriz to Istanbul after Chalderan conflict.

Keywords: Carpet, Turkmen, Aq Qoyunlu, Tabriz, Pattern.

\section{History of Aq Qoyunlus government}

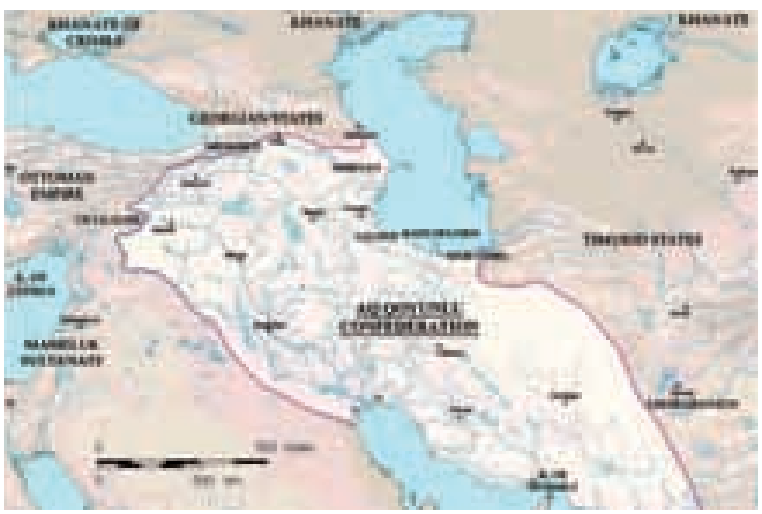

Map. 1, Territory of Aq Qoyunlu, second half of 15th century

The leaders of Aq Qoyunlu were from the Bayandur Oghuz clan ${ }^{1}$ and were considered descendants of the semi-mythical founding father of the Oghuz Khan. The Bayandurs behaved like statesmen rather than warlords and gained the support of the merchant and feudal classes of South Caucasus.

D. Bekir States; Turkish carpet art continued its development with the conquest of Anatolia by Turkish in 1071. Anatolian-Turkish carpet art originated from central Asia. The Turkish brought their carpet tradition with themselves when they came to Anatolia [and Iran] from Central Asia. After giving some information about West Anatolia in the book called Kitab bast u'larz fi'ttul ve'l arz, Ibn Said says the following... There are Turkman mountains and Turkman state in the western part of this region. Turkman people who are from the Turkish race conquered the Greek land during the Seljucks period...These people weaved Turkman carpets called "el busut-Turkmaniyye". ${ }^{2}$

With the conquest of Iran, not only did the Aq Qoyunlu center of power shift eastward, but Iranian influences were soon brought to bear on their meth-

1 C.E. Bosworth and R. Bulliet, The New Islamic Dynasties: A Chronological and Genealogical Manual, Columbia University, 1996, p. 275.

2 Bekir Deniz, "The Origins of the Art of Anatolian-Turkish Carpet Weaving", Akdeniz Sanat Dergisi, Sayı 2, 2008, p. 56 od of government and their culture. In the Iranian provinces, Uzun Hasan maintained the pre-existing administrative system along with its officials, whose families had in some cases served under different dynasties for several generations. ${ }^{3}$ There were only four top civil posts, all held by Iranians, in Uzun Hasan's time: those of the vizier, who headed the great council (divan); the mostawfi al-memalek, who was in charge of the financial administration; the mohrdar, who affixed the state seal; and the marakur (stable master), who looked after the royal court.

In letters from the Ottoman Sultans, when addressing the kings of Aq Qoyunlu, such titles as Malek al-Mulook al-Iraniyyeh (King of Kings of Iran), Sultan alSalatin Iraniyyeh (Sultan of Sultans of Iran), Shehanshah Iran Khadiv ajam (King of Kings of Iran and the Ruler of Persia), Jamshid Shawkat ve Fereydoon Raayat ve daaraa deraayat (Powerful like Jamshid, Flag of Fereydoon and Wise like Darius) have been used. ${ }^{4}$ Uzun Hasan also held the title "Padishah-i-Iran"(King-ruler of Iran), which was re-adopted again in the Safavid times through his grandson Ismail I, the founder of the Safavid dynasty

According to Byzantine chronicles, the Aq Ooyunlu were present in eastern Anatolia and north west of Iran from at least 1340, and most of their leaders, including the dynasty's founder, Uzun Hasan married Byzantine princesses. ${ }^{6}$

Aq Qoyunlu Turkmen first acquired land in 1402, when Tamerlane granted them all of Diyarbakır. For a long time, the Aq Qoyunlu were unable to expand their territory. However, this changed with the rule of Uzun Hasan who defeated the Qara Qoyunlu Turkmen leader, Jahān Shāh, in 1467.

After the defeat of a Timurid leader, Abu Sai'd, Uzun Hasan was able to take Baghdad, along with territories around the Persian Gulf. He expanded into Iran as far east as Khorasan. However, around this time, the Ottoman Empire thought to expand eastwards, a serious threat that forced the Aq Ooyunlu into an alliance with the Qaramanids of central Anatolia.

3 Jean Aubin. "Etudes Safavides: Shah Ismail I et les notables de l'Iraq Persan", JESHO 2, 1959, pp. 37-81.

4 Seyyed Ali Mua'yyad Sabeti, "Asnaad o Naameh-aayeh Tarikhi az Avael Dorrehaayeh Eslali taa Avakher 'And Shah Ismail Safavi" (historical sources and letters from the beginning of the Islamic era till the end of the era of Shah Ismail Safavi), Tehuri press, Tehran, 1366. pp. $422-430$

5 H.R. Roemer, "The Safavid Period", in Cambridge History of Iran, Vol. VI, Cambridge University, 1986, p. 339.

6 Robert Mac Henry. The New Encyclopedia Britannica, Encyclopedia Britannica, 1993, p. 184 
As early as 1464, Uzun Hasan had requested military aid from one of the Ottoman Empire's strongest enemies, Venice, however, despite Venetian promises, this aid never arrived, and as a result, Uzun Hasan was defeated by the Ottomans at Tercan in 1473, though this did not destroy the Aq Qoyunlus. When Uzun Hasan died early in 1478, he was succeeded by his son Khalil Mirza (Sultan Khalil), but the latter was defeated by a confederation under his younger brother Ya'qub at the Battle of Khoy in Azerbaijan Province. ${ }^{7}$

Ya'qub, who reigned from 1478 to 1490 , sustained the dynasty for a while longer. However, during the first four years of his reign there were seven pretenders to the throne who had to be put down. Following Ya'qub's death, civil war again erupted, the Aq Ooyunlus destroyed themselves from within, and they ceased to be a threat to their neighbours.

The Safavids and the Aq Qoyunlu met in battle at Nakhichevan in 1501, and the Safavid leader Shah Ismail forced the Aq Qoyunlu to withdraw .In his retreat from the Safavids, the Ak Koyunlu leader Alwand destroyed an autonomous Aq Qoyunlu state in Mardin. The last Ak Koyunlu leader, Murād, brother of Alwand, was also defeated by the same Safavid leader. Though Murād briefly established himself in Baghdad in 1508, he soon withdrew back to Diyar Bakr, signaling the end of the Ak Koyunlu rule.

Reports of western ambassadors and envoys from Aq Qoyunlu carpets

In 1463, the Venetian Senate, seeking allies against the Ottoman empire, sent Lazzaro Querini as its first ambassador to Tabriz. ${ }^{8}$

In 1473, Giosafat Barbaro was selected as another Venetian ambassador to Persia, due to his experience in the Crimean, Muscoy, and Tartary. ${ }^{9}$ Although Barbaro got on well with Uzun Hasan, he was unable to persuade the ruler to attack the Ottomans again. ${ }^{10}$ Shortly afterwards, Hassan's son Oğürlü Mohamed, rose in rebellion, seizing the city of Shiras. ${ }^{11}$

7 John E. Woods, The Aqquyunlu: Clan, Confederation, Empire, University of Utah Press, Salt Lake City, 1999, p. 128

8 Franz Babinger, Mehmed the Conqueror \& His Time, Princeton University; 1992, p.305

9 Hugh Murray, Historical account of discoveries and travels in Asia, Edinburgh, 1820, p. 10

10 William Bayne Fisher, Peter Jackson, Laurence Lockhart "The Cambridge history of Iran", Cambridge University, New York, 1986, p.377

11 Hugh Murray, Historical account of discoveries and travels in Asia, Edinburgh, 1820,p.15
After another Venetian ambassador, Ambroglio Contarini arrived in Persia, ${ }^{12}$ Uzun Hasan decided that Contarini would return to Venice with a report, while Giosafat Barbaro would stay. ${ }^{13}$ Barbaro was the last Venetian ambassador to leave Persia, after Uzun Hasan died in 1478. ${ }^{14}$ While Hassan's sons fought each other for the throne, Barbaro hired an Armenian guide and escaped. ${ }^{15}$

In this context, we would like to memoirs of Venetian traveler and envoy Giosafat Barbaro. In 1478, he arrived in Tabriz and described his audience with the Aq Qoyunlu ruler "Assambei" (Hasan bey, better Known as Uzun hasan) and the preparations for great public festival in Tabriz. In the narrative of his travels, Barbaro mentions carpets several times, but one comment in particular is often cited in the carpet literature. Here it is, as translated into English in sixteenth century:

The daye following I prepaired to him [the king] into a great feelde $w^{\text {thin }}$ the towne, wheare wheate had been sowen, the grasse whereof was mowed to make place for the tryomphe and the owners of the grounde satisfied for it. In this place were many pavilion pight [erected] me he comaunded certin of his to go $\mathrm{w}^{\text {th }}$ me, and to shew me those pavilions, being in nombre about an $c^{\text {th }}$, [one hundred] of the which I pused [perused] xl [forty] of fairest. They all had their chambers whinfoothe [interior room], and the roofes all cut of divers colors ${ }^{\mathrm{rs}}$, the grounde being covered $\mathrm{w}^{\text {th }}$ the most beautiful carpets, betwene which carpets and those of CAIRO and Borse (in my judgment), there is as much difference as betweene the clothes made of Englishe woolles and those of Saint Mathewes. ${ }^{16}$

To understand Giosafat Barbaro's comparison between the carpets he saw in Tabriz and those of Cairo and Bursa, It is necessary to give some explanation of each of the centers he mentions. Cairo was famous for mamluk carpets, while for Bursa we can read western Anatolian carpets, which Venetians would have purchased in Bursa incidental to their presence there to buy silk. To complete Barbar's comparison, in the first half of the sixteenth century English wool was widely recognized as the very best

12 William Bayne Fisher, Peter Jackson, Laurence Lockhart "The Cambridge history of Iran", Cambridge University Press, New York , 1986, p.377

13 Hugh Murray, Historical account of discoveries and travels in Asia, Edinburgh, 1820, p.19

14 Franz Babinger, Mehmed the Conqueror \& His Time, 1992, Princeton University; 1992, p.322

15 Hugh Murray, Historical account of discoveries and travels in Asia, Edinburgh, 1820, p.16

16 W. B. Denny, The Classical Tradition in Anatolian Carpets, The Textile Museum, Washington DC, 2003, pp.25-26. 
in the world, while the cloth of "saint mathewes" by which we may understand cloth of san Matteo was apparently cheap and low-quality woolens sold at the San Matteo market near Santo Spirito in Florence. ${ }^{17}$

Depictions in miniature paintings are of usefulness. A painted manuscript (Photo. 1) that survives from Aq Qoyunlu era, now in the Golestan palace museum in Tehran, shows scenes with carpets spread on floor and ground and people sitting on a carpet that appears to have a repeating pattern of small knotted-outlines borders similar to the some of Ushak carpets, with a white - on-red kufesque border. From this limited evidence we can reasonably infer that in the later part of fifteenth century carpets with Kufi designs were still quite common at the Aq Qoyunlu court and other cities under Aq Qoyunlu's territory as Shiraz in south west of Iran.

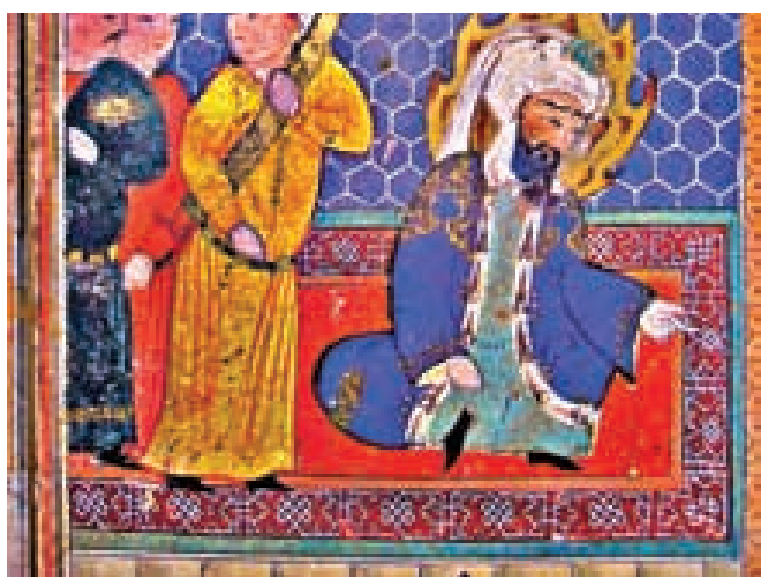

Photo. 1, Khavaran name, Golestan museum, Tehran

\section{Turkmen göls}

The göls themselves have great individual significance and some authorities attach much greater symbolic meaning to them that to any other oriental carpet motifs. W. Loges makes a distinction between göls, meaning the heraldic primary motifs of each tribe, and güls, motifs similar in construction but of secondary importance. In the past most people have assumed that the word göl is an etymological variant of the Persian or Sanskrit word 'gol' (گل), meaning flower, and those Turkmen motifs represent stylized flower forms. Thomas Knorr, however, states that göl is an ancient Turkish word meaning clan or family; and several other authorities have drawn attention to features of göl whose origins owe nothing to floral forms. Certainly it is now accepted that each tribe had its own göl and that when one tribe conquered

17. ibid, p. 25 another in battle the other defeated were obliged to use the victor's göl in their carpets and abandon their own.

The origin of the göls were often associated with the heradic birds which each turkmen rugs, widely portrayed in fifteenth-century Italian paintings, is based on repeating panels incorporating birds or other animals forms (Photo. 2). Such motifs undoubtedly had religious or totemic origins in pre-Islamic Asia, being used to propitiate the gods or ward off evil spirits. ${ }^{18}$
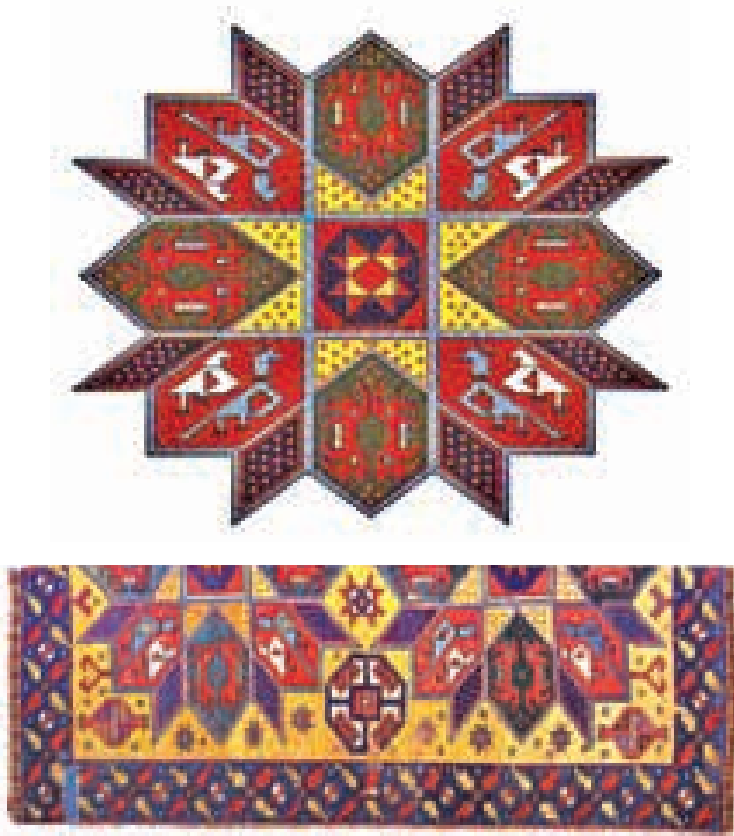

Photo. 2, Turkmen göl, a so-called "Crivelli carpet”, 15th century, Imparmüveszeti Museum, Budapest.

\section{Kufic border}

Kufic border is thought to derive from a specific Arabic script Termed "Kufi". An early form of Kufic border appears on $13^{\text {th }}$-century Saljuk carpet fragments. (photo. 3) It is common on Anatolian Holbein and Lotto carpets. The Kufic border is used on rugs of Shirvan and other Caucasian rugs. A line of Kufic script below is followed by a Kufic border from a $15^{\text {th }}$. century Rug. ${ }^{19}$

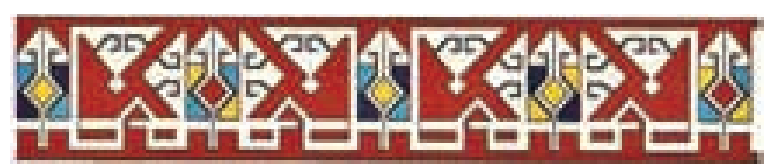

Photo. 3, Kufic border in Saljuk carpets, 13th century

18 P.R.J. Ford, Oriental Carpet Design, Thames and Hodson, London, 1997, p. 176

19 Peter. F. Stone, Tribal and village rugs. Thames \& Hudson, London, 2004, p. 172 
Karim MiRZAEE

As mentioned above, existent carpets in Aq Qoyun miniatures have Kufic borders. These borders generally have crimson ground. The most specific of these carpets is its location in Vakıflar Museum in Istanbul, which is depended to East Anatolia. Probably it goes back to $13^{\text {th }}$ century with kufic border.(Photo. 4) This carpet with a pure colorful ground has a border with well used knots. An exact corner making and minute arrangement explain the reality that these kind of carpets had one design upon which one weaver has knitted them. From the time of Saljuks, Kufic borders were used in Iran and Anatolia but the most Outstanding example is this one which has been followed afterwards.

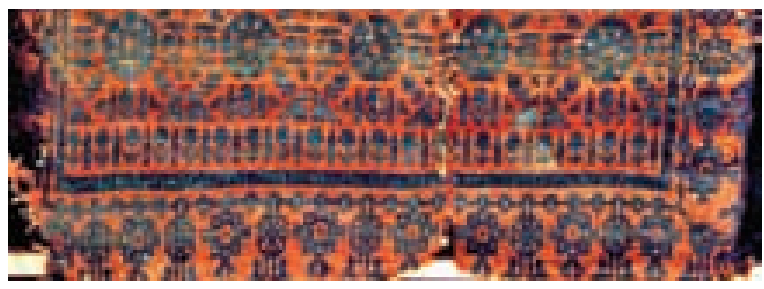

Photo. 4, Detail of a carpet with a Kufic border, 13th century,Vakıflar Museum, Istanbul

Here we would like to introduce two carpets that probably both of them have been woven in $15^{\text {th }}$ at Tabriz. Now those are kept in Wher collection, Switzerland and Philadelphia museum of art. They are with Kufic borders, with carefully used borders and corners, also with elegant and proportional size which remind Vakıflar carpet. No doubt both of them have outstanding and professional designers, who were painting in Turkmen courts. The carpet in wher collection has a dark-blue main border from old traditions of Azerbaijan carpets. (photo. 5)

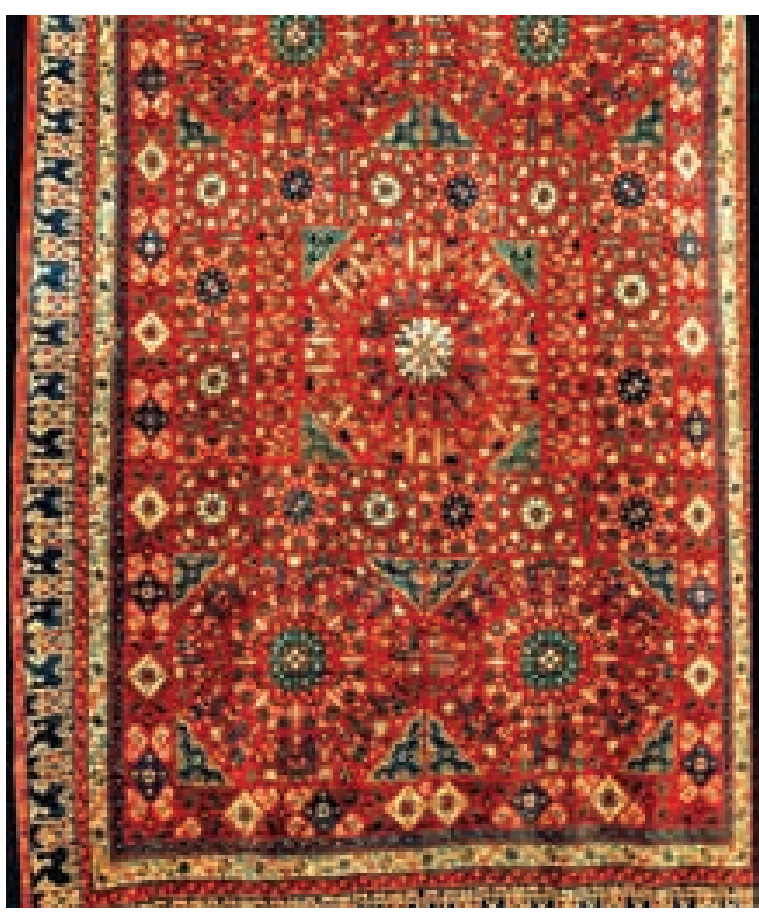

Photo. 5, A Tabriz carpet with a Kufic border, 15th century, Wher collection, Switzerland
A prominent sample is the border of Sheikh Safi carpet, later produced in Tabriz at Safavid era. It has to be mentioned that carpets of Central Iran, like Isfahan and Kashan possess crimson borders. Border of these two carpets remind Khavaran name miniatures, painted at Aq Qoyunlu era, a man called Farhad has painted on them at Shiraz. (photo. 6)

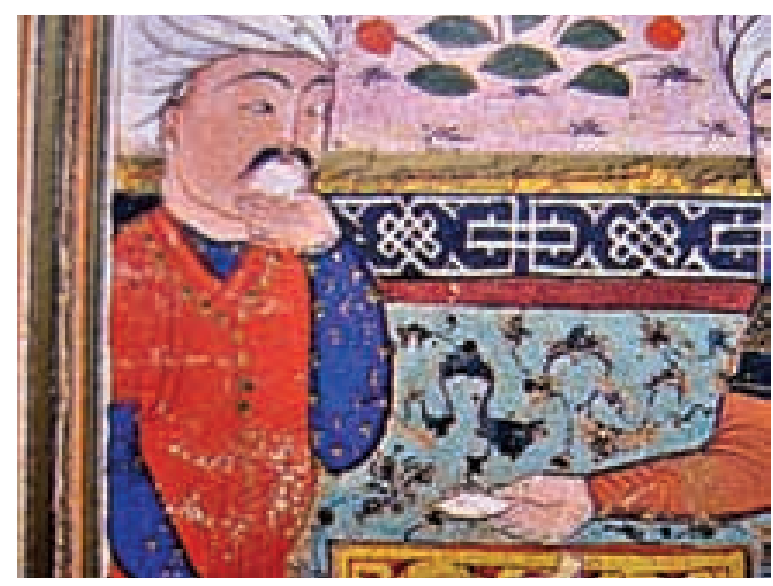

Photo. 6, a carpet with dark-blue border, Khavaran name, Golestan museum, Tehran

What was the main cause in using Kufic borders? Some of the researchers believe that, we can not find identity and quality of the carpets of clothes spread as footcloth, through miniatures. Because miniaturist could make changes in design and style, and there is no speaking picture for them in being as carpets.

In view of the writer, in miniatures of this period those carpets that have these kinds of borders are counted as piled carpets. For the following reasons:

A. The kind of designs of borders used as straight lines without curvature. This is because of the way of carpet weavings. Carpets of Aq Qoyunlu have low density, and for this reason, it was very difficult to weave crooked designs, and the artists preferred designs harmonious with carpet density.

B. If Kufic margin was merely a decorative strap near miniaturist, then why was it used more as liner on the carpets, while it could be used at tents, buildings and clothes? But it was avoided.

C. Continuation of applying kufic borders at real carpets (not the copy ones) at later period, on Safavid and Ottoman carpets, especially On Ushak ones, explains extension of a carpet designing tradition. A Kufic border not only at following periods, but today is seen in same Ardabil and Quba carpets.

Upon what was mentioned above, Kufic borders are one of the important decorations of carpets in Turkmen period, Therefore a miniaturist, with attention to the realities has adopted it in his works. 


\section{Octagon medallion}

As researchers state, octagon medallions used in carpets, gets its roots from Central - Asia carpet weaving. Turks of that area, after migration toward the West have had this sign and symbolic element with them.

Octagon medallions nowadays seen between Tribal carpet weavers of Yemut, Tekke and Choder in Central Asia, are in the following of the same designs used at previous centuries among immigrant tribes. This design has not only a special place at Central Asia, but also at Caucasus, Anatolia and North-west of Iran. Through this area it has been extended up to Damascus (sham), and Mamluk era in Egypt. Special big octagon medallion of those is called Mamluki or Para-Mamluki. This expression was so widely used among researchers that even carpets of other cities, with this kind of design were called Para-Mamluk. A main example is a carpet produced at $15^{\text {th }}$ century, probably in Tabriz, in the era of Aq Qoyunlus. (photo. 7) This Design has a Kufic border with Crimson ground, and an octagon medallion made from round Knots (Gireh) in the centre. The colour of Medallion is light, around rotating rays of young trees and flowers like Lotus (Shah Abbasi). Lotus with its special curvilinear is a beginning of a new epoch in designing and weaving of carpets, while later in Safavid and Ottoman Empire reached to its highest point in $16^{\text {th }}$ and $17^{\text {th }}$ centuries. Another four octagon medallion in four corners of the carpet reminds Central Asian art of carpet weaving, which has got its repetition in this carpet.

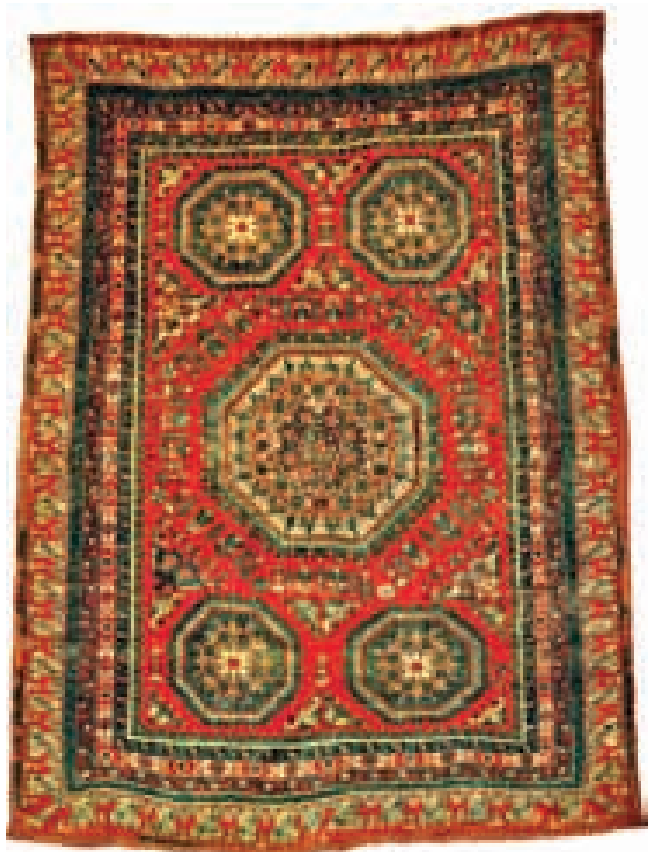

Photo. 7, a Tabriz carpet with octagon medallions, 15th century Museum of art, Philadelphia.
Another carpet from $15^{\text {th }}$ century is probably Tabriz, Aq Qoyunlu, with thin Kufic border and several slim margins which covers a wide ground of the carpet. The ground of the carpet is Crimson with repeated octagon medallions. In another word, medallion setting, in contrary to Philadelphia's sample (Photo. 7), is not defined with around lines, but only by repetition of elements as young trees similar to cypress and lotus, we may notice octagon design. The carpet has a big-size medallion in the centre and four middle-size one in four corners of the carpet and several small-size octagon medallions between five mentioned above medallions. (Photo. 5)

The another carpet that is attributed to Turkmen or Timrod era by B. Balpınar and U. Hirsch is from Divriği Ulu Mosque collection. On blue background, there exist octagons placed on each other and squares sides of which are hooked inside. Inside the squares, hand on hips motifs. There are seen in kilim and zili weavings. Especially in Sivrihisar and Afyon weavings. It is stated that this carpet is also from $14^{\text {th }}-15^{\text {th }}$ century. On the side borders there exist -S - motifs and motifs which look like Kufi writing. ${ }^{20}$ (Photo. 8)

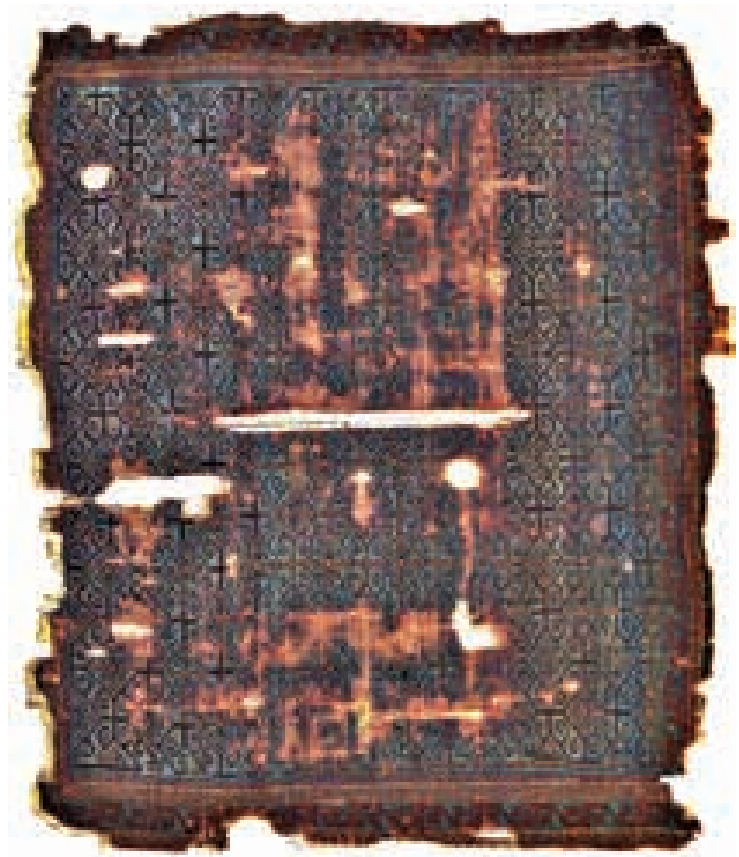

Photo. 8, An Aq Qoyunlu carpet, 14th - 15th century, Carpet Museum, Ankara.

\section{Strap-work Star}

The characteristics of the group include designs based on complex girih geometric forms, including

20 S. Bayraktaroğlu and S. Özçelik, Carpet Museum and Kilim and Flatweaving Rugs Museum Catalogue. Turkish Republic Prime Minister Directorate General of Foundation, 2007, p. 9 
Karim MiRZAEE

what we call a "strap-work star", an eight pointed star-like form that appears to be interlaced from one continuous ribbon or strap, and an "early' kufic border patterned on Arabic calligraphy. The eightpointed "strap-work" stars seen in the fragment are related to another medallions which there are strong reasons for attributing as the $13^{\text {th }}$ century till $15^{\text {th }}$ century. (photo. 9)

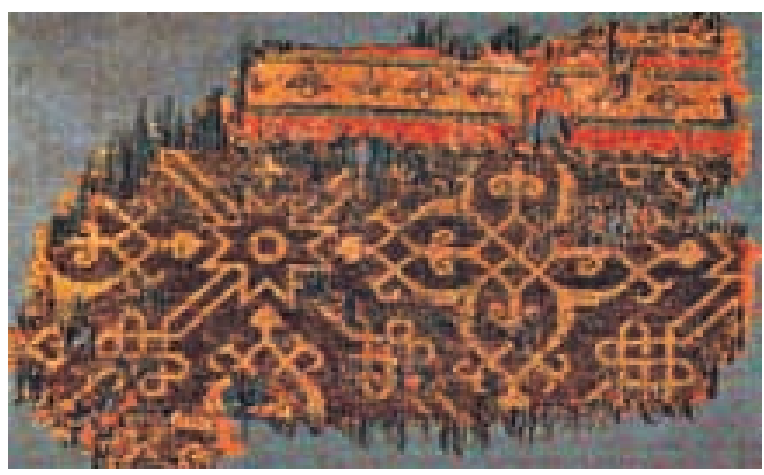

Photo. 9, probably Azerbaijan, 1270-1470, Heinrich Kirchheim Stuttgard.

As Wlter B. Denny stresses carpets such as these may well have been the "Tabriz" carpets noted by Barbaro in 1474, which he thought to be superior to those of Bursa and Cairo. They were probably conceived at the court of the Aq Qoyunlu Türkmen rulers in Tabriz, and woven in very small numbers in an atelier under the direct control of the court. They appear to be the inspiration for slightly later carpets woven in Egypt, Syria, and Anatolia. Some of them are very closely allied in design with the earliest carpets of the large-pattern Holbein group. In many respects they represent the apogee of geometric carpet design before the "carpet design revolution" of the late $15^{\text {th }}$ century, a phenomenon that probably also began in Azerbaijan and Anatolia. ${ }^{21}$ (Photo. 10)

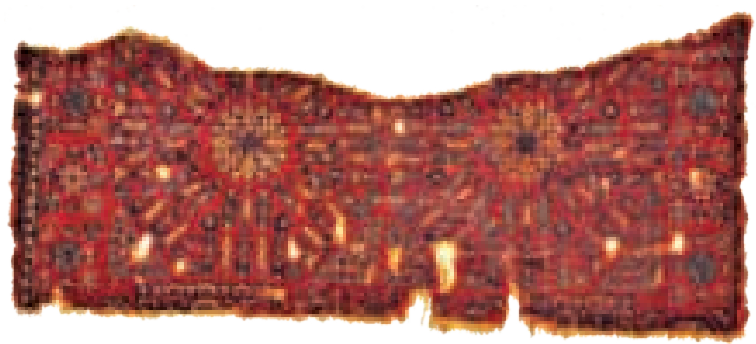

Photo. 10, detail of a Tabriz carpet with two octagon medallions, 15th century, Textile Museum

Strap-work or knotted (girih) stars are other elements in Aq Qoyunlu carpets. The color of the stars is cream, generally located inside octagon medal-

21 Walter. B. Denny, The Classical Tradition in Anatolian Carpets, The Textile Museum, Washington DC, 2003, p. 61. lions and sometimes they are separate. Strap-work eight-point stars have the most harmony with Kufic border. Also light cream color in direct and oblique lines is generally in synchronization with Kufic border lines and it creates special balanced composition. In the main time it attracts elements around it and protects it from dispersion.

It has to be mentioned, that Holbein carpets have influenced by Aq Qoyunlu carpets. Because with their Kufic borders and strap-work medallions they follow the tradition of $15^{\text {th }}$ century carpets from Tabriz. (photo. 11)

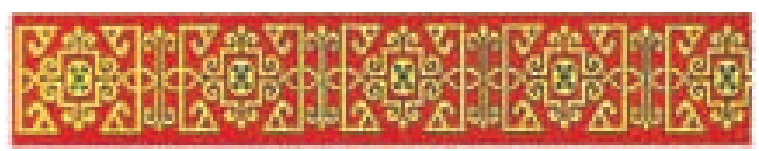

Photo. 11, Kufic border in Aq Qoyunlu carpets, 15th century.

Regular Diagonal coloring adds interest to simple field eight-pointed stars or octagrams inside octagons. Octagrams-in-octagons are a common element in motifs. The Persian term for this element is "Jows" or "walnut". ${ }^{22}$ In octagram and star medallion there is a motion from the center outward, In Aq Qoyunlu carpets there is octagram within an octagon within octagram within octagon. The overall shape of these star medallions is quite old, particularly appearing in Tabriz $15^{\text {th }}$-century carpets. (Photo. 12) They appear as a field repeat in $13^{\text {th }}$-century east Anatolia rug too.

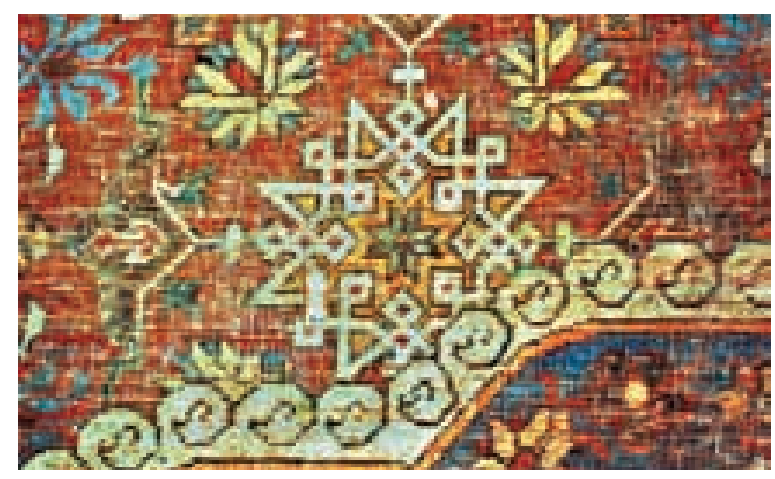

Photo. 12, Detail of a Tabriz carpet with a strap-work star element, Late 15th century, Museum of Fine Arts, Boston

\section{A Pre-Safavid Persian carpet}

A north west medallion carpet is one of the several such pieces about which experts differ with regard to their dates. Grote - Hasenbalg described this carpet as around 1500, Dimand, suggests an even earlier date. Erdmann attributes to sixteenth century. (Photo. 13)

22 Peter. F. Stone, Tribal and village rugs. Thames \& Hudson, London, 2004, p.252. 


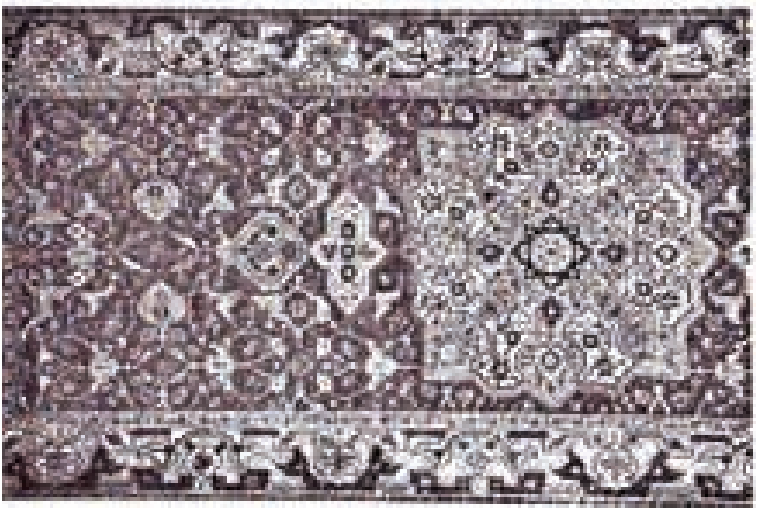

Photo.13, Carpet with geometric precursor of Herati pattern, 15th century, Formerly collection Freiherr Tucher von Simmelsdorf Vienna.

Grote-Hasenblag sees all of this kind of carpets as a residue of the strict style of the fifteenth century. A point that he does not mention is that they all also use a geometric variant of the Herati pattern in the ground, suggesting link between it and the arabesques of Islamic art of an earlier period. Dimand shows how the Tabriz Designers gradually overcame this stiffness and introduced the flowing style seen in some Heart miniatures. ${ }^{23}$

It is essential to point out that we don't need to appoint this carpet design to Heart miniature, because Tabriz has been very vigorous and active art center in Aq Qoyunlus period particularly under Uzun Hasan and his sons rule. Another reason can be the writing of envoys who visited the Hesht Behesht palace and the carpets they saw in There that had been woven from silk. Aq Qoyunlu rulers adorned their tents with plenty of carpets and rugs, too. ${ }^{24}$ In the other hand as Susan Day states, unlike Tabriz, on early references to Heart as a weaving center have yet come to light. The fact that the weaving of Afghan tribes who inhabit the region bear no relation. ${ }^{25}$

\section{References}

B. Josafa, and a. Contarini, Travel to Tana and Persia,Translated from the Italian by William Thomas, London, 1478.

Bekir Deniz, "The Origins of the Art of Anatolian-Turkish Carpet Weaving", Akdeniz Sanat Dergisi. Sayı 2, 2008.

C.E. Bosworth and R. Bulliet, The New Islamic Dynasties: A Chronological and Genealogical Manual, Columbia University, 1996.

Franz Babinger, Mehmed the Conqueror \& His Time, Princeton University; 1992.

J. Fr. Michaud; Louis Gabriel "Biographie universelle, ancienne et moderne", Michaud, Paris, 1811-28.

Jean Aubin. "Etudes Safavides: Shah Ismail I et les notables de l'Iraq Persan", JESHO 2, 1959.

John E. Woods, The Aqquyunlu: Clan, Confederation, Empire, University of Utah Press, Salt Lake City, 1999.

H.R. Roemer, "The Safavid Period", in Cambridge History of Iran, Vol. VI, Cambridge University, 1986.

Hugh Murray, Historical account of discoveries and travels in Asia, Edinburgh, 1820.

P.R.J. Ford, Oriental Carpet Design, Thames and Hodson, London, 1997.

Peter. F. Stone, Tribal and village rugs. Thames \& Hudson, London, 2004.

Robert Mac Henryz. The New Encyclopedia Britannica, Encyclopedia Britannica, 1993.

Seyyed Ali Mua'yyad Sabeti, “Asnaad o Naameh-aayeh Tarikhi az Avael Dorrehaayeh Eslali taa Avakher 'Ahd Shah Ismail Safavi" (historical sources and letters from the beginning of the Islamic era till the end of the era of Shah Ismail Safavi), Tehuri press, Tehran, 1366.

Suzan. Bayraktaroğlu and Serpil Özçelik, Carpet Museum and Kilim and Flatweaving Rugs Museum Catalogue. Turkish Republic Prime Minister Directorate General of Foundation, 2007.

Susan. Day, Great Carpets of The World, Thames and Hudson. London, 1996.

Walter. B. Denny, The Classical Tradition in Anatolian Carpets, The Textile Museum, Washington DC, 2003

William Bayne Fisher, Peter Jackson, Laurence Lockhart "The Cambridge history of Iran", Cambridge University Press, New York, 1986.
23 P. R. J. Ford, Oriental Carpet Design, Thames and Hodson, London, 1997, p. 80.

24 Bekir. Deniz, "The Origins of the Art of Anatolian-Turkish Carpet Weaving", Akdeniz Üniversitesi Güzel Sanatlar Fakültesi yayını, Sayı 2 . 2008, p. 58

25 Susan. Day, Great Carpets of The World, Thames and Hudson. London, 1996, p. 121 